\title{
RANTAI PEMASARAN IKAN PINDANG DI KABUPATEN PATI
}

\section{MARKETING CHAIN OF BOILED FISH IN PATI REGENCY}

\author{
Herna Octivia Damayanti \\ Kantor Penelitian dan Pengembangan Kabupaten Pati \\ Email: octivia_oc@yahoo.co.id
}

Naskah Masuk: 2 April 2015 Naskah Revisi: 10 April $2015 \quad$ Naskah Diterima: 22 April 2015

\begin{abstract}
A good pattern marketing chain can determine the smoothness of product distribution and becomes the determinant of continuity and development of an industry. Boiled fish industry is the second largest fish processing industry in Pati Regency. The objective of this research is to determine the pattern of boiled fish marketing chain in Pati regency on household, small, medium and large industrial scales. This research used descriptive method and was held on March 2014. Location of the research in Juwana and Dukuhseti subdistrict. Primary data was obtained through interviews with informants, i.e. the owners of boiled fish industries on households, small, medium and large scales. Data was analyzed descriptively. Result of the research is there are two types of boiled fish marketing chain in Pati regency, i.e. direct marketing is called zero level channel (households and small industry scales) and marketing through intermediaries that consist of first channel or three level channel (household industry scale); the second channel or one level channel (scale households and small industries); and the third channel or two levels channel (scale medium and large industrial).
\end{abstract}

Keywords: boiled fish industry, marketing chain through intermediaries, direct marketing chain

\begin{abstract}
ABSTRAK
Rantai pemasaran yang terpola dengan baik dapat menentukan kelancaran distribusi produk dan menjadi penentu keberlangsungan hidup dan perkembangan suatu industri. Industri ikan pindang merupakan industri pengolahan ikan kedua terbesar di Kabupaten Pati. Tujuan dari penelitian ini adalah untuk mengetahui pola rantai pemasaran ikan pindang yang ada di Kabupaten Pati pada skala industri rumah tangga, kecil, sedang dan besar. Penelitian ini menggunakan metode deskriptif dan dilaksanakan bulan Maret 2014. Lokasi penelitian di Kecamatan Juwana dan Dukuhseti. Data primer didapatkan melalui wawancara dengan informan/pengusaha ikan pindang skala rumah tangga, kecil, sedang dan besar. Analisis data dilakukan secara deskriptif. Hasil penelitian adalah rantai pemasaran ikan pindang di Kabupaten Pati terdapat dalam dua jenis yaitu pemasaran secara langsung disebut saluran nol tingkat (skala industri rumah tangga dan kecil) dan pemasaran melalui perantara terdapat dalam bentuk saluran pertama disebut saluran tiga tingkat (skala industri rumah tangga); bentuk saluran kedua disebut saluran satu tingkat (skala industri rumah tangga dan kecil); bentuk saluran ketiga disebut saluran dua tingkat (skala industri sedang dan besar).
\end{abstract}

Kata kunci: industri ikan pindang, rantai pemasaran melalui perantara, rantai pemasaran langsung 


\section{PENDAHULUAN}

Industri pemindangan ikan merupakan salah satu upaya untuk mempertahankan atau menjaga kualitas dan harga jual ikan (Larasati, 2007). Pengolahan ikan pindang atau pemindangan merupakan salah satu cara pengolahan atau pengawetan ikan secara tradisional yang cukup populer di Indonesia, dan dalam urutan hasil olahan tradisional menduduki tingkat kedua setelah ikan asin (Komariyah, 2004).

Industri ikan pindang berkembang di daerah yang memiliki wilayah pesisir, salah satunya di Kabupaten Pati. Data dari Dislautkan Kabupaten Pati tahun 2013 menunjukkan jumlah industri pemindangan adalah 104 industri yang terdiri dari skala industri rumah tangga, kecil, sedang dan besar. Industri pemindangan merupakan industri pengolahan hasil perikanan terbesar kedua setelah industri pengasapan/pemanggangan (berjumlah 309 industri).

Kapasitas produksi industri ikan pindang Kabupaten Pati adalah 123.595 kg/hari (Dislautkan Kab. Pati, 2014), dengan produksi yang demikian besar maka kegiatan pemasaran produk menjadi hal yang penting, karena berhubungan dengan terdistribusinya produk ikan pindang yang dihasilkan.

Rantai pemasaran yang terpola dengan baik dapat menentukan kelancaran distribusi produk. Selain itu, rantai pemasaran dapat menjadi penentu keberlangsungan hidup dan perkembangan suatu industri karena produk yang dihasilkan dapat dijual ke pasar sehingga mendatangkan pendapatan bagi suatu usaha. Dengan demikian, tujuan dari penelitian ini adalah untuk mengetahui pola rantai pemasaran ikan pindang yang ada di Kabupaten Pati pada skala industri rumah tangga, kecil, sedang dan besar.

\section{TINJAUAN PUSTAKA}

\section{Ikan Pindang}

Pindang merupakan hasil olahan ikan dengan cara kombinasi perebusan/pemasakan dan penggaraman. Pindang mempunyai penampakan, citarasa, tekstur dan keawetan yang khas dan bervariasi sesuai dengan jenis ikan, kadar garam, dan lama perebusan. Jenisjenis yang umum diolah dengan cara pemindangan adalah jenis ikan pelagis seperti layang, selar, japu, tembang, lemuru, kembung, tuna, cakalang, tongkol, dan lain-lain. Selain itu di beberapa tempat terdapat juga jenis ikan lain seperti cucut dan petek (Anonim, $t \mathrm{t}$ ). Soeyanto dalam Larasati (2007) menyatakan bahwa ada beberapa cara pembuatan ikan pindang yaitu: 1) Pemindangan sistem Bawean; 2) Pemindangan sistem Muncar; 3) Pemindangan dengan besek; dan 4) Pemindangan dengan sistem gantung.

Adapun tujuan utama proses pengolahan pemindangan ikan (Media Penyuluh Perikanan Pati, 2013) adalah: (a) Mencegah/memperlambat proses pembusukan terutama pada saat produksi melimpah. Khusus untuk wilayah pesisir yaitu hasil penangkapan pada musim ikan bulan Juli dan Agustus; (b) Menambah nilai jual produk mentah menjadi bahan olahan; (c) Mempertahankan kualitas/mutu dan meningkatkan harga jual ikan; (d) Meningkatkan pendapatan bakul ikan; (f) Membuat nilai tambah sehingga dapat meningkatkan penjualan; (g) Memperhatikan unsur kesehatan dan kebersihan ikan.

\section{Pemasaran}

Pemasaran adalah merupakan serangkaian proses kegiatan atau aktivitas yang ditujukan untuk menyalurkan barang-barang atau jasa-jasa dari titik produsen ke titik konsumen (Limbong dan Sitorus dalam Adida dkk, 2013). 
Fungsi pemasaran meliputi: 1) Fungsi pertukaran yaitu kegiatan-kegiatan yang terlibat di dalam pemindahan hak milik barang dan jasa; (2) Fungsi fisik adalah kegiatan-kegiatan yang terlibat di dalam perlakuan perpindahan dan perubahan fisik secara aktual dari komoditas tertentu. Fungsi fisik ini terdiri dari fungsi penyimpanan, pengolahan, dan transportasi; 3) Fungsi fasilitas yaitu kegiatan untuk memperlancar pelaksanaan dari fungsi pertukaran dan fungsi fisik. Fungsi fasilitas ini terdiri dari fungsi standarisasi, pembiayaan, penanggungan risiko, dan fungsi informasi pasar.

\section{METODE PENELITIAN}

Penelitian ini menggunakan metode deskriptif. Penelitian dilaksanakan pada bulan Maret 2014. Penelitian dilakukan pada industri ikan pindang yang beroperasi sepanjang tahun di Kecamatan Juwana dan Dukuhseti. Data primer didapatkan melalui wawancara dengan informan/pengusaha ikan pindang yang meliputi industri ikan pindang skala sedang di Desa Bajomulyo, Desa Dukutalit untuk industri ikan pindang dengan skala besar, Desa Banyutowo untuk industri ikan pindang dengan skala rumah tangga dan kecil. Pengelompokan skala industri ikan pindang berdasarkan jumlah tenaga kerja yang dimilikinya yaitu untuk industri skala besar mempunyai tenaga kerja 100 orang atau lebih, skala industri sedang mempunyai tenaga kerja 20-99 orang, skala industri kecil mempunyai tenaga kerja 5-19 orang dan skala industri rumah tangga mempunyai tenaga kerja 1-4 orang (BPS Prov. Jateng, 2013). Sedangkan data sekunder didapatkan melalui literatur yang relevan. Analisis data dilakukan secara deskriptif untuk menggambarkan rantai pemasaran ikan pindang bagi masing-masing skala industri.

\section{HASIL DAN PEMBAHASAN}

Proses pemasaran produk ikan pindang di Kabupaten Pati terdapat dalam berbagai bentuk. Perbedaan proses pemasaran atau yang biasa disebut rantai pemasaran terjadi karena produsen ikan pindang (pengusaha ikan pindang) terdiri dari berbagai skala industri. Hasil penelitian terhadap pengusaha ikan pindang menunjukkan terdapat 2 bentuk rantai pemasaran ikan pindang yaitu: 1) Pemasaran yang dilakukan secara langsung dari produsen ke konsumen: dan 2) Pemasaran yang melalui perantara. Namun demikian, untuk pemasaran melalui perantara panjang rantai/salurannya berbeda-beda tergantung dari jumlah perantara yang harus dilalui sebelum produk sampai ke konsumen. Menurut Hanafiah dan Saefuddin dalam Anisah dan Susilowati (2007), panjang pendeknya saluran pemasaran/rantai pemasaran suatu barang tata niaga, ditandai oleh berapa banyaknya pedagang perantara yang dilalui oleh suatu komoditas.

\section{Rantai Pemasaran Secara Langsung}

Rantai pemasaran pertama yaitu pemasaran secara langsung. Bentuk pemasaran langsung yang dimaksud adalah produk ikan pindang yang dihasilkan oleh produsen langsung dipasarkan sendiri kepada konsumen. Berdasarkan hasil wawancara dengan informan pengusaha ikan pindang, pola rantai pemasaran secara langsung dilakukan oleh pengusaha ikan pindang dengan skala industri rumah tangga dan kecil di Desa Banyutowo Kecamatan Dukuhseti. Carani (2006) menyebutkan bahwa salah satu cara produsen (industri kecil) dalam menjual produk yang dihasilkan adalah menjual sendiri dengan cara ecer di pasar. 


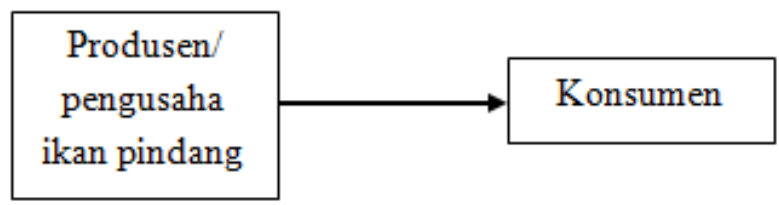

\section{Gambar 1.}

\section{Skema Rantai Pemasaran Secara Langsung}

Kaunang dkk (2012) menyebutkan bahwa skema pada Gambar 1 disebut saluran nol tingkat yaitu terdiri dari seorang produsen yang langsung menjual ke pelanggan terakhir.

Alasan dilakukannya pemasaran produk secara langsung kepada konsumen karena jumlah produksi yang relatif kecil yaitu berkisar antara 20-50 kg/hari. Jumlah produksi ikan pindang untuk skala industri rumah tangga dan kecil di Kabupaten Pati menurut data Dislautkan Kabupaten Pati yaitu 10-100 kg/hari. Penyebab dari relatif kecilnya kapasitas produksi pada industri skala rumah tangga dan kecil adalah penggunaan teknologi yang masih sederhana dan modal yang terbatas. Soesanto dalam Carani (2006) menyebutkan bahwa industri kecil dalam melakukan kegiatan produksinya menggunakan teknologi yang sederhana. Wardhono dalam Carani (2006) juga menyebutkan bahwa hambatan klasik yang biasa ditemui bagi munculnya industri kecil yang tangguh adalah sektor permodalan.

Kendala lain yang harus dihadapi oleh pengusaha skala industri rumah tangga dan kecil selain teknologi dan modal, sebagaimana disebutkan oleh Tambunan dalam Carani (2006) yaitu kurangnya akses terhadap pasar dan dukungan kebijaksanaan terhadap industri masih belum sekuat dukungan kepada industri besar dan sedang. Dengan demikian, pengusaha skala industri rumah tangga dan kecil khususnya ikan pindang hanya mampu memasarkan produksinya secara langsung di pasar-pasar lokal dengan kisaran harga Rp4000 sampai Rp5000 per besek (per besek berisi 4-5 ekor ikan pindang).

\section{Rantai Pemasaran Melalui Perantara}

Kohl dan Downey dalam Carani (2006) menyebutkan bahwa salah satu lembaga pemasaran adalah lembaga perantara baik sebagai individu maupun sebagai perusahaan bisnis yang berspesialisasi dalam membentuk berbagai fungsi pemasaran yang terlibat dalam pembelian dan penjualan barang dan jasa atau perpindahan barang dan jasa dari produsen ke konsumen. Lembaga perantara ini dikelompokkan ke dalam: 1) Pedagang perantara (merchant middlement) yang terdiri dari pengecer (retailers) dan grosir (wholesalers); 2) Agen perantara (agent middlement) yang terdiri dari brokers dan komisi (commision); 3) Pengolah (processors) dan pengusaha pabrik (manufacturers); dan (4) Organisasi fasilitas (fasilitative organizations).

Lembaga pemasaran yang digunakan untuk pemasaran ikan pindang di Kabupaten Pati adalah pedagang perantara atau pengepul. Rantai pemasaran ikan pindang di Kabupaten Pati yang menggunakan perantara terbagi dalam 3 saluran. Saluran pertama yaitu dari produsen disetorkan terlebih dahulu ke produsen yang lebih besar, kemudian produk diambil oleh pengepul. Dari pengepul produk dijual ke pedagang dan dari pedagang produk langsung dijual ke konsumen ikan pindang. 


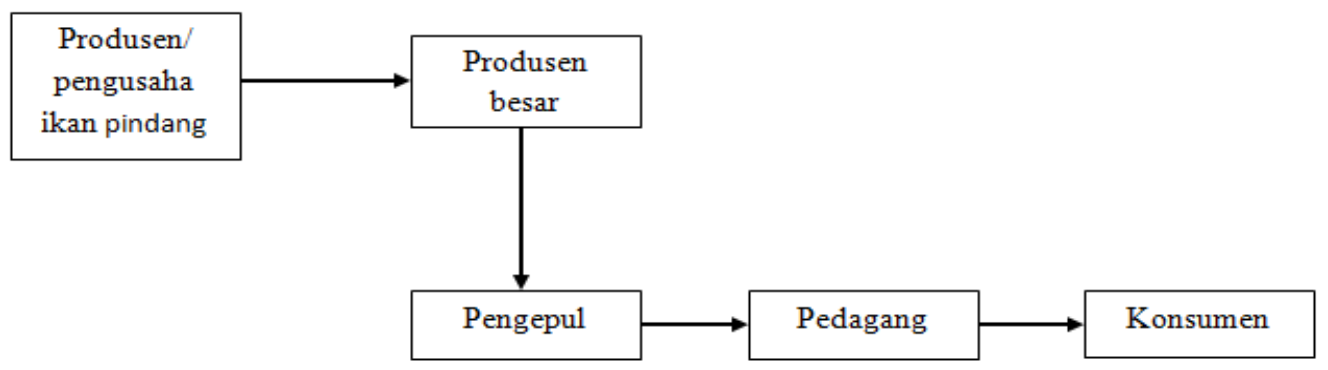

\section{Gambar 2.}

\section{Skema Rantai Pemasaran Melalui Perantara (Bentuk Saluran Pertama)}

Pola rantai pemasaran seperti pada Gambar 2 dilakukan oleh pengusaha ikan pindang dengan skala industri rumah tangga di Desa Banyutowo Kecamatan Dukuhseti. Pola yang diterapkan yaitu produsen kecil (biasanya pengusaha ikan pindang skala rumah tangga) menyetor produknya ke produsen lain yang lebih besar (pengusaha ikan pindang skala kecil). Dalam hal ini, produsen yang lebih besar berperan sebagai pengepul pertama dari produsen-produsen lain.

Produk ikan pindang yang telah terkumpul di pengepul pertama kemudian diambil oleh pengepul kedua (pedagang besar). Dari pengepul kedua ini, produk dijual ke pedagang-pedagang yang lebih kecil untuk selanjutnya dijual kembali kepada konsumen. Kaunang dkk (2012) menyebutkan bahwa pola pemasaran yang terdiri dari tiga perantara disebut saluran tiga tingkat. Ketiga perantara yang dimaksud dalam hal ini yaitu pengepul pertama (produsen besar), pengepul kedua (pedagang besar) dan pedagang kecil.

Berdasarkan hasil wawancara dengan informan yang menggunakan pola pemasaran dengan skema pada Gambar 2, alasan yang mendasari yaitu: 1) Jumlah produksi yang relatif kecil sehingga produsen enggan untuk melakukan penjualan secara langsung karena akan menambah biaya operasional yaitu untuk transportasi menuju tempat penjualan; 2) Produsen besar dianggap memiliki jaringan pemasaran yang lebih luas sehingga produsen kecil tidak khawatir jika produknya tidak akan laku terjual. Harga jual ikan pindang di tingkat produsen kecil ini sama dengan harga jual yang berlaku pada penjualan langsung yaitu kisaran harga Rp4000 sampai Rp5000 per besek (per besek berisi 4-5 ekor ikan pindang). Sedangkan untuk harga jual yang berlaku di tingkat perantara tidak diketahui secara langsung oleh produsen.

Saluran kedua yaitu produk ikan pindang diambil oleh pedagang eceran. Kemudian dari pedagang kecil produk langsung dijual ke konsumen ikan pindang. Pola rantai pemasaran ini, dilakukan oleh pengusaha ikan pindang dengan skala industri rumah tangga dan kecil di Desa Banyutowo Kecamatan Dukuhseti. Pola yang diterapkan yaitu produsen menjual produk ikan pindangnya kepada pedagang eceran. Selanjutnya pedagang eceran inilah yang nantinya akan menjual produk kepada konsumen. 


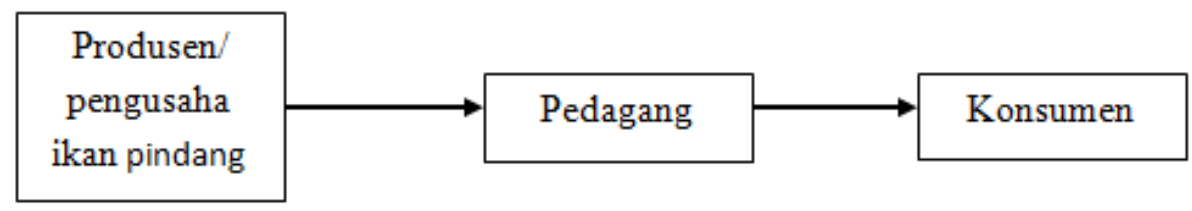

Gambar 3.

Skema Rantai Pemasaran Melalui Perantara (Bentuk Saluran Kedua)

Jika dilihat dari skema pada Gambar 3, maka terdapat satu perantara yaitu pedagang kecil/pedagang eceran. Dalam Kaunang dkk (2012) disebutkan bahwa saluran pemasaran dengan menggunakan satu perantara disebut saluran satu tingkat, dimana perantara ini biasanya adalah pedagang eceran.

Primadistya (2004) dalam makalahnya menyebutkan bahwa pedagang eceran (retailing) termasuk semua aktivitas dalam menjual barang atau jasa, langsung ke konsumen akhir untuk kebutuhan pribadi dan non-bisnis. Pengecer terdiri dari pengecer toko dan non-toko. Pedagang pengecer yang dimaksud disini adalah pedagang pengecer non-toko.

Hasil wawancara dengan responden yang menggunakan skema pada Gambar 3 , alasan yang mendasari yaitu produsen langsung didatangi oleh pedagang eceran. Pedagang eceran ini merupakan pedagang yang memasarkan produk ikan pindang untuk pasar-pasar lokal. Alasan pedagang eceran mengambil langsung produk ikan pindang dari produsen adalah harga jual dari produsen relatif lebih murah dibandingkan jika mengambil dari pengepul atau pedagang besar. Harga jual yang berlaku sama untuk semua produsen atau pengusaha ikan pindang skala industri rumah tangga dan kecil baik yang berlaku pada penjualan langsung yaitu kisaran harga Rp4.000 sampai Rp5.000 per besek (per besek berisi 4-5 ekor ikan pindang).

Saluran ketiga yaitu dari produsen, ikan pindang diambil oleh pengepul (pedagang pemesan ikan pindang), kemudian dari pengepul produk dijual ke pedagang yang lebih kecil untuk selanjutnya dijual ke konsumen. Pola pemasaran ini dilakukan oleh pengusaha ikan pindang dengan skala industri sedang dan besar. Kapasitas produksi ikan pindang untuk skala industri sedang dan besar berkisar antara 3.000-9.000 kg/hari (Dislautkan Kab. Pati, 2014). Informan pengusaha ikan pindang skala industri sedang dan besar berasal dari Desa Dukutalit dan Desa Bajomulyo Kecamatan Juwana.

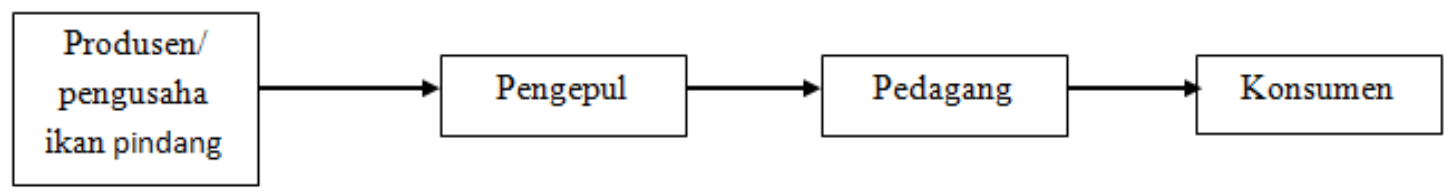

\section{Gambar 4.}

Skema Rantai Pemasaran Melalui Perantara (Bentuk Saluran Ketiga)

Skema pada Gambar 4 menunjukkan terdapat dua perantara yaitu pengepul/pedagang besar dan pedagang kecil/eceran. Bentuk rantai pemasaran seperti pada Gambar 4, identik dengan bentuk saluran pemasaran II pada 
penelitian Fitriana yaitu dari petani/produsen dijual ke tengkulak kemudian ke pedagang eceran selanjutnya dijual ke konsumen (Fitriana dalam Agustina, 2008). Sedangkan dalam Kaunang dkk (2012), bentuk pemasaran dengan dua perantara disebut saluran dua tingkat.

Hasil wawancara dengan informan yang menggunakan skema pada Gambar 4 bahwa para pengusaha ikan pindang baik untuk skala industri sedang maupun besar di Kabupaten Pati dalam melakukan proses produksi sangat tergantung dari pesanan pengepul (dalam hal ini pedagang besar). Biasanya tiap pengusaha ini sudah mempunyai pengepul langganan. Pengepul ini berasal dari luar Kabupaten Pati seperti beberapa daerah di Jawa Tengah (Kudus, Semarang, Wonosobo, Magelang, Wonogiri, Solo, dan lain-lain), Yogyakarta dan Jawa Timur, sehingga pengusaha ikan pindang skala industri sedang dan besar di Kabupaten Pati tidak menjual produknya di dalam daerah Kabupaten Pati.

Pengusaha ikan pindang skala industri sedang dan besar di Kabupaten Pati (produsen) ini sangat bergantung kepada pengepul. Hal ini dikarenakan pengepul inilah yang menentukan jumlah produksi dari industri ikan pindang sang pengusaha. Alasan yang dikemukakan responden adalah dengan pola produksi menurut jumlah pesanan maka tidak perlu khawatir jika produk tidak habis terjual. Tetapi kekurangan dari pola ini adalah pengepul biasanya melakukan pembayaran setelah produk dikirim atau setelah produk terjual dari pengepul (sistem berhutang terlebih dahulu) sehingga responden banyak mengeluhkan kesulitan mencari modal baru untuk kembali berproduksi. Harga jual produk ikan pindang di tingkat produsen tergantung dari jenis bahan baku yang digunakan. Untuk bahan baku ikan layang harga jual Rp30.000/gendel (1 gendel 12 besek), untuk bahan baku ikan banyar harga jual Rp30.000 sampai Rp35.000/gendel (1 gendel 12 besek), untuk bahan baku ikan tongkol harga jual Rp30.000 sampai Rp35.000/gendel (1 gendel 9 besek), dan untuk bahan baku ikan salem harga jual Rp60.000/gendel (1 gendel 9 besek). Isi ikan pindang untuk berbagai jenis bahan baku adalah 2 ekor per besek.

\section{KESIMPULAN DAN SARAN}

\section{Kesimpulan}

Rantai pemasaran ikan pindang di Kabupaten Pati terdapat dalam dua jenis yaitu pemasaran secara langsung dan pemasaran melalui perantara. Untuk pemasaran secara langsung disebut juga saluran nol tingkat (tidak melalui perantara) digunakan oleh industri ikan pindang dengan skala industri rumah tangga dan kecil. Untuk pemasaran melalui perantara terdapat tiga bentuk. Bentuk saluran pertama disebut saluran tiga tingkat (menggunakan tiga perantara) dan digunakan oleh industri ikan pindang dengan skala industri rumah tangga di Desa Banyutowo Kecamatan Dukuhseti. Bentuk saluran kedua disebut saluran satu tingkat (menggunakan satu perantara) dan digunakan oleh industri ikan pindang dengan skala industri rumah tangga dan kecil. Bentuk saluran ketiga disebut saluran dua tingkat (menggunakan dua perantara) dan digunakan oleh industri ikan pindang skala industri sedang dan besar.

\section{Saran}

1. Bagi dinas terkait, khususnya Dislautkan Kab. Pati untuk mulai mengalihkan program pengembangan industri perikanan ke arah industri rumah tangga dan kecil dan Disperindag Kab. Pati untuk membantu membuka akses pemasaran lebih luas bagi industri perikanan skala industri rumah tangga dan kecil. 
2. Bagi dinas terkait, khususnya Dislautkan dan Disperindag Kab. Pati perlu melakukan koordinasi bersama dengan membentuk wadah bersama yang khusus mengawasi dan mengatur kegiatan pengepul/tengkulak.

\section{DAFTAR PUSTAKA}

Adida, K. N., S. Harijati. 2013. Efisiensi Pemasaran Ikan Gurami (Oshpronemus Gouramy) Ukuran Konsumsi di Kelurahan Duren Mekar dan Duren Seribu, Depok Jawa Barat. Prosiding Seminar Nasional Riset dan Kebijakan Sosial Ekonomi Kelautan dan Perikanan Tahun 2013. Semarang: Badan Penelitian dan Pengembangan Kelautan dan Perikanan.

Agustina, L. 2008. Analisis Tataniaga dan Keterpaduan Pasar Kubis (Studi Kasus Desa Cimenyan, Kecamatan Cimenyan, Kabupaten Bandung, Provinsi Jawa Barat). Skripsi. Program Studi Ekonomi Pertanian dan Sumberdaya Fakultas Pertanian. Bogor: Institut Pertanian Bogor.

Anisah, R. N., I. Susilowati. 2007. Kajian Manajemen Pemasaran Ikan Pindang Layang di Kota Tegal. Jurnal Pasir Laut 3(1): 1-18.

Anonim. tt. Ikan Pindang. Tekno Pangan dan Agroindustri 1(8): 116-119.

Badan Pusat Statistik Provinsi Jawa Tengah. 2013. Jawa Tengah Dalam Angka 2012. Semarang: BPS Provinsi Jawa Tengah.

Carani, I. 2006. Analisis Kinerja Saluran Pemasaran Industri Kecil Tahu Kasus Pengrajin Tahu Kelurahan Pasir Jaya, Kecamatan Bogor Barat. Skripsi. Program Studi Manajemen Agribisnis Fakultas Pertanian. Bogor: Institut Pertanian Bogor.
Dinas Kelautan dan Perikanan Kabupaten Pati. 2014. Profil Pindang Pati. Pati.

Kaunang, J. D., W. Uguy dan Ch. Ngangi. 2012. Strategi Pemasaran Industri Rumah Tangga Gula Aren di Kota Tomohon. Laporan Penelitian. Manado: Universitas Sam Ratulangi.

Komariyah. 2004. Formulasi Strategi Usaha Pengolahan Hasil Perikanan Laut Secara Tradisional Di Kota Pekalongan. Tesis. Magister Manajemen Sumberdaya Pantai Semarang: Universitas Diponegoro.

Larasati, E. 2007. Analisis Usaha Pemindangan Ikan Di Kabupaten Pati. Skripsi. Fakultas Pertanian. Surakarta: Universitas Sebelas Maret.

Media Penyuluh Perikanan Pati. 2013. Pengolahan Hasil Perikanan Dengan Pemindangan. (http://media penyuluh perikanan pati.blogspot.com/2013/06/pengola han-hasil-perikanan-dengan.html, diakses tanggal 20 Januari 2014).

Primadistya, K. E. 2004. Mengelola Pedagang Eceran, Grosir, dan Logistik. Makalah. Fakultas Ekonomi. Jakarta: Universitas Trisakti.

\section{BIODATA PENULIS}

Herna Octivia Damayanti, lahir 6 Oktober 1985 di kota Kudus Jawa Tengah. Pendidikan S1 Program Studi Oseanografi Jurusan Ilmu Kelautan Fakultas Perikanan dan Ilmu Kelautan Universitas Diponegoro tahun 2009. Saat ini bekerja sebagai Peneliti di Kantor Penelitian dan Pengembangan Kabupaten Pati. 